\title{
厓挡
}

\author{
高血圧性脳出血に対する手術法と手術適応 \\ 一定位法を中心に一 \\ 本 藤 秀 樹
}

\section{Standard Surgical Techniques and Surgical Indications for Hypertensive Intracerebral Hemorrhage}

by

Hideki Hondo, M.D.

from

Department of Neurological Surgery, School of Medicine, The University of Tokushima

There are 2 surgical approaches to hypertensive intracerebral hemorrhage; open craniotomy and stereotactic aspiration surgery (SAS) and neurosurgeons should be familiar with both procedures. In open craniotomy, the transsylvian or transcortical approach can be used when the patient is in a very acute stage and hemostasis is required to provide a clear field of vision under the microscope. The incidence of postoperative seizure is lower in the transsylvian than the transcortical approach.

SAS is the less invasive of the 2 procedures. It can be carried out under local anesthesia, the operative time is short and the required instrumentation is relatively simple. Deep-seated hematomas (thalamic or pontine hemorrhage) can also be aspirated using SAS and the procedure may be appropriate for elderly or high-risk patients.

Positioning of the needle for aspiration can be achieved with ultrasound-guided, CT-guided (with or without a localizing frame), or MRI-guided stereotaxy. The CT-guided method is most commonly employed. Various mechanical devices have been tested in attempts to improve clot removal, e.g. the Archimedes screw; a coaxial double cannula, the ultrasonic aspirator, and the water jet.

Before surgery, the presence of vascular lesions (aneurysms, arteriovenous malformations (AVM), dural AVMs, cryptic AVMs, cavernous hemangiomas, and cerebral amyloid angiopathy) should be ruled out by cerebral angiography, MRA (Magnetic Resonance Angiography) or 3 D-CTA (3 dimensional CT angiography). SAS should not be performed earlier than at least 6 hours after onset. To avoid intraoperative bleeding, not more than $70 \%$ of the clot should be aspirated initially. Blood pressure must be carefully controlled during the aspiration procedure. The residual hematoma should be drained out by urokinase infusion within 3 days of the initial aspiration. SAS may be indicated for patients with putaminal hemorrhage where the hematoma volume is greater than $30 \mathrm{ml}$, for cerebellar hemorrhage patients with a hematoma volume greater than $15 \mathrm{~m} l$, for thalamic hemorrhage patients with a hematoma volume greater than $10 \mathrm{ml}$ and for subcortical hemorrhage patients with a hematoma volume greater than $20 \mathrm{~m} l$. The role of SAS in patients with pontine hemorrhages remains to be determined.

(Received July 21, 1998; accepted December 10, 1998)

Key words : intracerebral hemorrhage, open craniotomy, CT stereotaxy, aspiration surgery

Jpn J Neurosurg (Tokyo) 8: 69-76, 1999

徳島大学医学部脳神経外科(連絡先：本藤秀樹, $\overline{\mathbf{T} 770-8539}$ 徳島市蔵本町 1-10-30 徳島県立中央病院脳神経外科)

Address reprint requests to: Hideki Hondo, M.D., Department of Neurosurgery, Tokushima Prefectural Central Hospital,

1-10-30 Kuramoto-cho, Tokushima-shi, Tokushima 770-8539, Japan 


\section{はじめに}

高血圧性脳出血に対する手術療法は, 開頭血腫除去術 と定位的血腫吸引術があるが，何がスタンダードな手術 かは時代によって，また施設によっても変わってくると

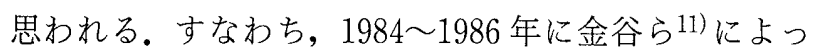
て行われた急性期被殸出血の全国調查では, 外科療法 3,216 例のうち開頭術が $76 \%$, 血腫吸引術が $24 \% て ゙$, その当時は開頭術がスタンダードな手術法であった。し かし, 現在では CT 装置や周辺機器の発達により, 侵襲 の少ない定位的血腫吸引術が主流になってきているが， この定位的血腫吸引術がすべての症例に適応できるわけ ではなく，超急性期で出血が持続している症例などには 対応できない.いずれにしても, 高血圧性脳出血を取り 扱う脳神経外科医は両方の手術法に精通していることが 望ましい. 本稿では, 脳出血の鑑別診断, 開頭血腫除去 術と定位的血腫吸引術の方法とそのポイント, 手術適応 について述べる。

\section{鑑別診断}

脳出血の手術法として定位的血腫吸引術を選択する場 合は，血管異常や腫瘍などの原因疾患を否定しておく必 要がある。脳出血の原因には, 高血圧性以外に脳動脈瘤 や脳動静脈奇形 (AVM), 硬膜動静脈瘦, cryptic AVM, 海綿状血管腫, モヤモヤ病, 脳腫瘍, 出血性梗 塞, アミロイドアンギオパシー, 特発性血小板減少性紫 斑病や白血病や肝硬変などに伴う出血傾向, 抗血小板薬 や抗凝固療法に伴う出血などがある23）(Fig. 1). 患者 が壮年あるいは高齢者で高血圧症の既往があり, 出血の 部位が典型的な好発部位であれば，高血圧性脳出血の可 能性が高い. しかし, 若年者で出血の部位が皮質下の場 合は, 脳動静脈奇形やモヤモや病あるいは脳腫崵が原因 となることがあるので, 造影 CT あるいは脳血管撮影 (MRA，3 D-CTA を含む) で確認すべきである. 高齢 者の皮質下出血で, 再発を繰り返したり多発性の出血が ある場合はアミロイドアンギオパシーを疑う。

\section{手術方法}

1 開頭血腫除去術

\section{1. 被殻出血}

被殼出血に対しては, 経側頭葉法と経シルビウス 法28)の 2 つの方法がある (Fig. 2). 皮膚切開は, 前頭 側頭部にクエッションマーク型, あるいは線状切開を加
える、脳浮腫が強く, 血腫除去後に骨弁の除去が考えら れる場合は, 大きなクエッションマーク型の皮膚切開を 置く. 経側頭葉法は, 開頭し硬膜を切開したあと, 顕微 鏡下に血腫直上の皮質を約 $10 \mathrm{~mm}$ 切開し，血腫腔に到 達し，直視下に血腫を除去する方法である，血腫を除去 する場合，太めの吸引管を使い，顕微鏡の鏡筒を左右前 後に傾け，脳べラをうまく使って血腫を吸引すると血腫 の取り残しが少ない. 出血点がみられる場合は確実に止 血する.一方, 経シルビウス法は顕微鏡下にシルビウス 裂のクモ膜を切開し島(insula)に至り，島表面の皮質を 5〜10 mm 切開し血腫腔に到達する方法である.この 際, シルビウス静脈や島表面の動静脈を損傷しないよう 注意する。経シルビウス法は経側頭葉法に比べて大脳皮 質の損傷が少なく, 術後痙攣の頻度が少ない利点があ る24)。いずれの方法でも，血腫を除去したあと穿通枝 動脈からの出血があれば，出血点を双極凝固子で凝固止 血する. 血腫壁からの oozing はオキシセルなどで圧迫 止血する，出血がないことを確認した後閉頭するが，血 腫除去後も脳浮腫が強い時は減圧のため骨弁を除去し, 後日脳浮腫が軽減した時点で頭蓋形成術を行う。

\section{2. 小脳出血}

全身麻酔下に腹臥位で後頭部に正中切開，または馬蹄 型の皮膚切開を加え後頭下開頭を行う. 後頭骨は両側と も十分切除し，下方は減圧のため大孔縁を開放し，小脳 扁桃ヘルニアが起こっている場合は環椎後弓を切除す る ${ }^{33)}$. 血腫の脳室穿破による水頭症がある場合は後角 穿刺により脳圧をコントロールする。硬膜を $\mathrm{Y}$ 字型に 切開し，血腫直上の小脳半球または虫部を $5 \sim 10 \mathrm{~mm}$ 切 開し，血腫を顕微鏡下に除去する，血腫が第 4 脳室に穿 破している場合は，第 4 脳室底を損傷しないように注意 する．血腫除去後, 出血点が確認できれば確実に止血す る，出血がないことを確認し，筋肉，皮虐を縫合する. 重症型や激症型の出血では, 血腫による脳幹の不可逆的 変化が起こっては術後の回復が見込めないので, 後頭下 開頭術を行う場合はできるだけ手早く行う必要がある。

\section{3. 皮質下出血}

皮質下出血は前頭葉, 側頭葉, 頭頂葉, 後頭葉のいず れにも起こるので，開頭はそれに対応する部位を開頭す る. 硬膜を切開したあと, 顕微鏡下に皮質を切開し血腫 を除去するが，血腫が eloquent area にある場合はその 部位の切開はできるだけ避ける。術中エコーで血腫部位 を確認すれば，正確な皮質切開が可能である ${ }^{33)}$ 。また 血腫除去に際しても, 血腫辺緑の脳実質はできるだけ吸 引しないように注意を払う。皮質下出血は, 特に若年者 では出血の原因となる cryptic AVM や血管腫や腫場が 

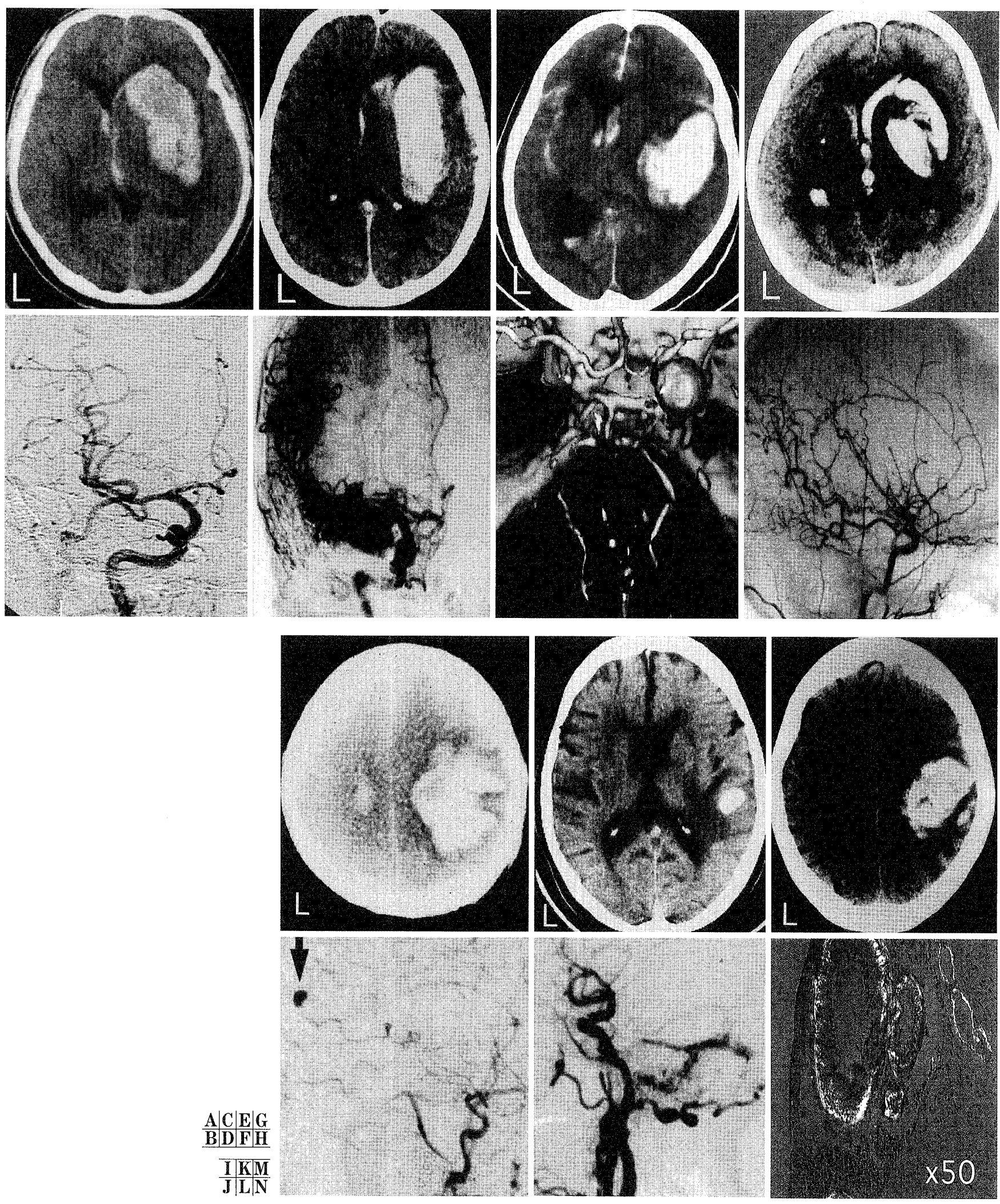

Fig. 1 Before surgery, the presence of vascular lesions should be ruled out by angiography, MRA or 3D-CTA.

A, B : Hypertensive putaminal hemorrhage

C, D : Arteriovenous malformation

E, F : IC-PC aneurysm

G, H : Moyamoya disease
$\mathbf{I}, \mathbf{J}$ : Mycotic aneurysm

$\mathbf{K}, \mathbf{L}$ : Dural arteriovenous fistula

M, $\mathbf{N}$ : Cerebral amyloid angiopathy 


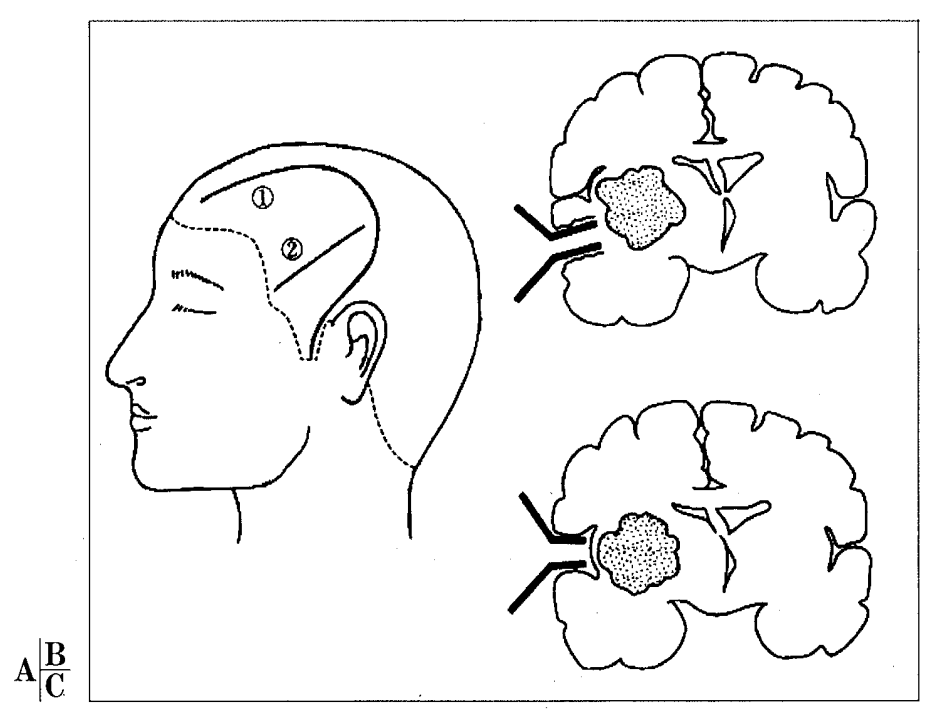

Fig. 2 In open craniotomy the transsylvian or transcortial approach can be used.
A: Two types of skin incision
B : Transcortical approach
C : Transsylvian approach

隠れていることがあるので, 血腫壁の組織学的検索が重 要である31).

\section{2 定位的血腫吸引術}

\section{1. 定位法}

定位的血腫吸引術において，血腫の位置を決定する定 位法には CT を利用する方法2)388)1921)，MRI を利用す る方法 ${ }^{9)}$, 術中に超音波を利用する方法 ${ }^{4}$, 画像誘導下 のナビゲータを使うもの13)30)32)などが報告されている. 装置の使いやすさと正確度から CT 利用する方法が最 も普及している，この CT 定位血腫吸引術は，頭部に位 置決めのゲージ板を装着する方法（駒井式 ${ }^{14)}, \mathrm{BRW}$ 式5)など）と， CT 室で定位脳手術装置を頭部に固定し，

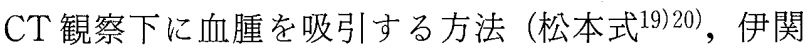
式8)，Patil 式 ${ }^{25)}$ など）がある. 本邦では駒井式が普及 しているが，後者の方が血腫吸引直後に何\%の血腫が吸 引されているかを知ることができるし，術中出血があっ てもただちに対応できる利点がある。

\section{2. 血腫吸引方法}

急性期の血腫は比較的硬く, 注射器による吸引では十 分に吸引できず，太い吸引管で無理に吸引すると術中出 血の危険性がある。そこで血腫吸引のために Archimedes screw を利用した吸引(針2) 12)，ジェット水流を利用した 吸引管 ${ }^{10)}$, 超音波血腫吸引装置 ${ }^{20)}$, 内視鏡下の血腫吸 引1116)などが工夫されている。 また，残存血腫に対して urokinase を局所纪投与して融解排除する方法3)18) も報 告されている.

\section{3. 血腫吸引の実際}

定位的血腫吸引術の実際は装置によって異なるので，

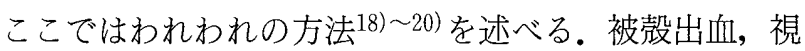
床出血の場合は前頭部に bregma より $2 \mathrm{~cm}$ 前方で, 正 中より $2.5 \sim 4 \mathrm{~cm}$ 側方に局所麻酔下に約 $4 \mathrm{~cm}$ の皮膚切 開を加え穿頭する．視床出血の場合は，穿刺針が側脳室 を通過しないようにやや側方に穿頭する，小脳出血，脳 幹出血では後頭部に，正中より $4 \sim 5 \mathrm{~cm}$ 側方，横静脈 洞より 2 3cm 下方に穿頭する．この際，肩が邪魔に なることがあるので，手回しの穿頭器よりクラニオトー ムの方が穿頭しやすい.

次に CT 室で頭部を CT 用定位脳手術装置に固定する (Fig. 3)．血腫中心部，穿頭部，穿刺針の CT 画像をと り，これらの座標をパーソナルコンピュータにインプッ トすれば，自動的に穿刺針の角度と深さが表示される。 表示通り穿刺針の角度を調整し，再度 CT をとり，穿刺 針が正しく血腫中心部に向かっていることを確認した後 穿刺針を刺入する。ここで CT をとり，穿刺針の先端が 正しく血腫中心部に入っていれば超音波血腫吸引装置で 吸引を開始する。吸引時の血圧コントロールは術中出血 の予防に非常に重要である7). 推定血腫量の約 $70 \%$ を 吸引した時点で CTをとり，再出血がないことを確認 し，血腫腔にドレーンを留置し手術を終える。

血腫が脳室穿破し閉塞性水頭症を併発している場合 は，同側または反対側に脳室ドレナージを併設する，血 腫が脳室穿破している場合は血腫の吸引が不十分になる ことがあるので，吸引針のターゲットを穿破部位から離 れた場所に置く。術後にドレーンから urokinase を注 入し，残存血腫を融解排除する。通常，術後 $2 \sim 3$ 日で 血腫は排除される。

血腫吸引の時期は，再出血を避けるため原則として発 作汃ら 6 時間目以降に行っている. 発作超早期に急速に 血腫が増大する症例は開頭して出血点を止血する必要が ある．定位的血腫吸引術中に再出血をきたした場合は， ただちに血圧を下げ，吸引管はそのままに留置して止血 を待つ. 出血が止まらなければ開頭して直視下に止血す る必要がある。

\section{手術適応}

高血圧性脳出血の手術適応についてはいまだ議論のあ るところで，手術方法によってもその適応は変わってく ると思われる。1980〜1994 年までに，徳島大学とその 関連施設で経験した定位的血腫吸引術の症例は 645 例 （被殼出血 450 例，小脳出血 38 例，視床出血 135 例，橋 

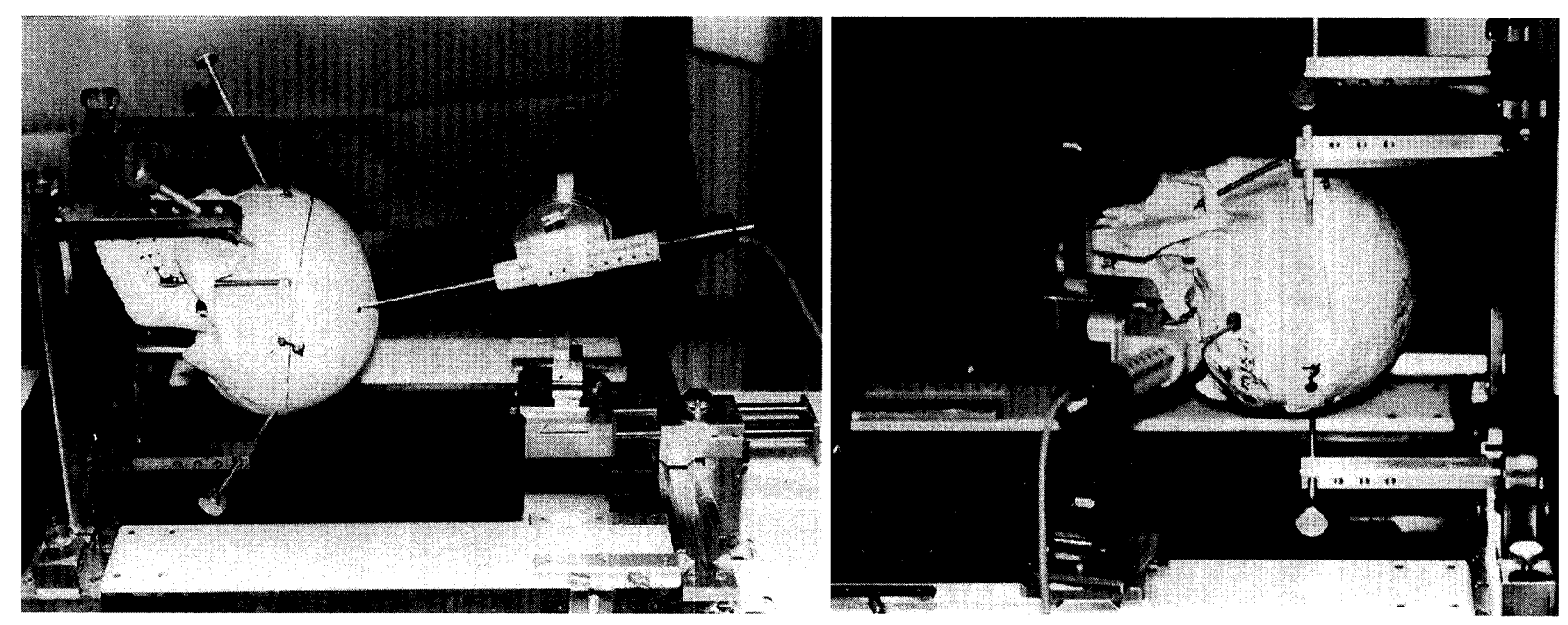

$\overline{\mathbf{A} \mid \mathbf{B}}$

Fig. 3 CT-controlled stereotactic apparatus

A : Frontal approach

B : Posterior fossa approach

出血 6 例，皮質下出血 16 例）で，この自験例を基に手 術適応について述べる。

\section{1 被殻出血}

金谷 ${ }^{11)}$ は急性期被款出血の全国調査から手術のガイ ドラインを示している，それによると意識レベルが傾眠 〜半昏睡（神経学的重症度 2 4）で，血腫量が $30 \mathrm{~m} l$ 以上の症例に手術適応があるとしている。特に $50 \mathrm{~m} l$ 以 上では，開頭血腫除去術を勧めている。しかし，血腫吸

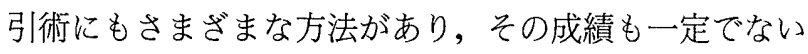
と思われる。そこで, 自験例の血腫吸引術の成績を血腫 量別に全国調查の内科療法と開頭血腫除去術の成續とを 比較した (Fig. 4)。なお，各治療群間の有意差検定は Mann-Whitney testを利用した。

血腫量が $10 \mathrm{~m} l$ 以下の群では，内科療法の転帰が開頭 術よりも優れており，吸引術とは差がなかった。血腫量 が 11〜 30 $\mathrm{m} l$ の群では, 内科療法の転帰は開頭術よりも 優れており, 吸引術とは差がなかった。外科療法のう ち，吸引術の転㷌は開頭術よりも良かった(Fig. 4)。血 腫量が $31 \sim 50 \mathrm{~m} l$ の群と $51 \sim 70 \mathrm{~m} l$ の群では, 吸引術と 開頭術の転帰は内科療法よりも優れており，吸引術と開 頭術の成績は差がなかった(Fig. 4). 血腫量が 71〜100 $\mathrm{m} l$ の群では, 吸引術と開頭術の転帰は内科療法より優 れており，吸引術と開頭術の成績は差がなかった，血腫 量が $101 \mathrm{~m} l$ 以上の群ではいずれも死亡率が高くなるが, 吸引術と開頭術の成績は内科療法よりも優れていた。外 科療法のうち, 開頭術の成績は吸引術の成績よりも優れ ていた (Fig.4).

したがって，われわれの定位的血腫吸引術では，50 $\mathrm{m} l$ を超える大型の血腫でも開頭術と同等の成績が得ら
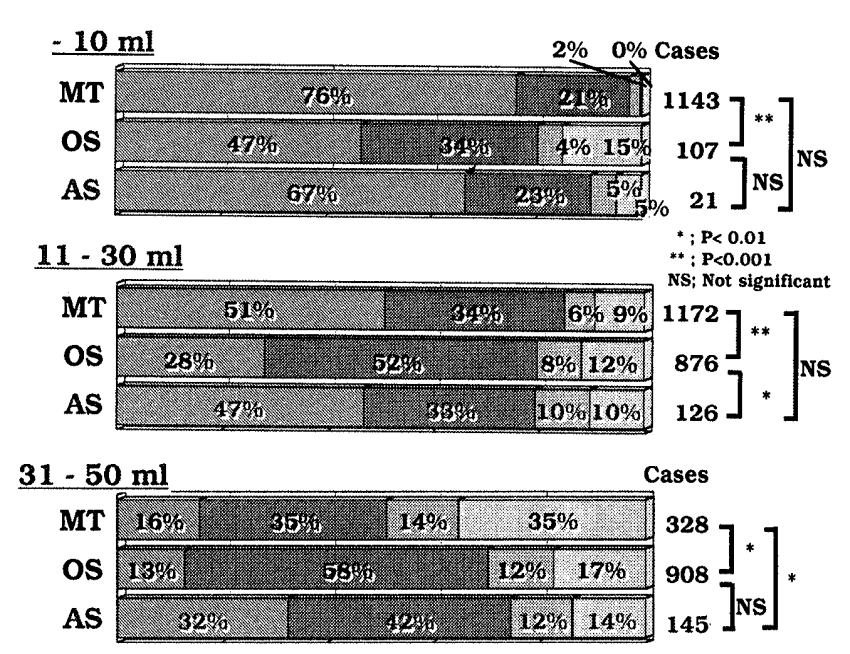

$$
\begin{array}{lr}
51-70 \mathrm{ml} & * ; p<0.01 \\
& \text { Ns; not significant }
\end{array}
$$

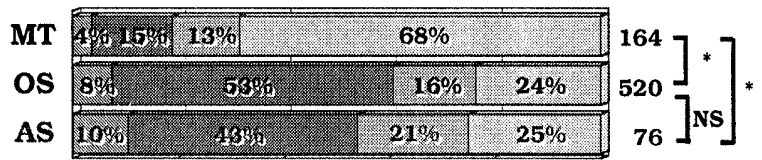

\section{$71-100 \mathrm{ml} 2 \% 2 \% \quad$ Cases

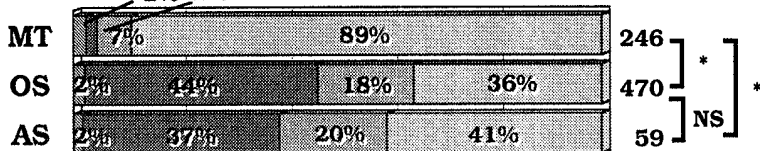
$\begin{array}{rlll}101 \mathrm{ml}- & 0 \% \quad 3 \% \quad 3 \% & * ;<<0.01, * * * p<0.05 \\ \text { NS; not significant }\end{array}$

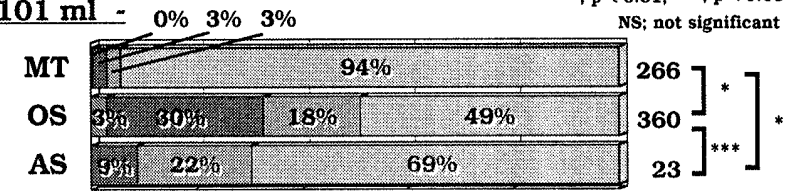

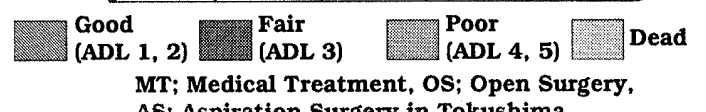
AS; Aspiration Surgery in Tokushima

Fig. 4 Hematoma volume $(-10 \mathrm{~m} l, 11-30 \mathrm{~m} l, 31-50 \mathrm{~m} l$, 51-70 $\left.l, 71-100 \mathrm{~m} l, 101 \mathrm{~m} l^{-}\right)$and 3-month outcome of putaminal hemorrhage patients 
Table 1 Three-month outcome of cerebellar hemorrhage

\begin{tabular}{|c|c|c|c|c|c|c|c|}
\hline \multirow{2}{*}{ Type } & \multirow{2}{*}{ Treatment } & \multicolumn{5}{|c|}{ 3-month outcome } & \multirow{2}{*}{ Total } \\
\hline & & Good & Fair & Poor & Dead & & \\
\hline \multirow{4}{*}{$\begin{array}{l}\text { Benign } \\
(\mathrm{NG} 1,2)\end{array}$} & MT & $61(85)$ & $9(13)$ & $1(1)$ & $1(1)$ & & 72 \\
\hline & $\mathrm{VD}$ & $1(50)$ & $1(50)$ & 0 & 0 & & 2 \\
\hline & $\mathrm{SC}$ & 0 & 0 & 0 & 0 & & 0 \\
\hline & AS & $1(50)$ & $1(50)$ & 0 & 0 & & 2 \\
\hline \multirow{4}{*}{$\begin{array}{c}\text { Moderate } \\
(\mathrm{NG} 1,2)\end{array}$} & MT & $9(56)$ & $4(25)$ & $1(6)$ & $2(13)$ & & 16 \\
\hline & $\mathrm{VD}$ & $10(91)$ & $1(9)$ & 0 & 0 & & 11 \\
\hline & $\mathrm{SC}$ & $11(79)$ & $3(21)$ & 0 & 0 & & 14 \\
\hline & AS & $6(60)$ & $4(40)$ & 0 & 0 & & 10 \\
\hline \multirow{4}{*}{$\begin{array}{l}\text { Severe } \\
(\mathrm{NG} 3,4)\end{array}$} & $\mathrm{MT}$ & 0 & 0 & $1(50)$ & $1(50)_{-}$ & \multirow{4}{*}{ * } & 2 \\
\hline & VD & $1(8)$ & $2(17)$ & $3(25)$ & $6(50) *$ & & 12 \\
\hline & $\mathrm{SC}$ & $13(41)$ & $9(28)$ & $3(9)$ & $7(22) \perp$ & & 32 \\
\hline & AS & $7(37)$ & $5(26)$ & $1(5)$ & $6(32)$ & & 19 \\
\hline \multirow{4}{*}{$\begin{array}{l}\text { Fulminant } \\
(\mathrm{NG} 5)\end{array}$} & MT & 0 & 0 & 0 & $22(100)-\eta^{*}$ & \multirow{4}{*}{]$_{*}^{*}$} & 22 \\
\hline & VD & 0 & 0 & $1(8)$ & $11(92)$ & & 12 \\
\hline & $\mathrm{SC}$ & $1(8)$ & $2(15)$ & $3(23)$ & $7(54)$ & & 13 \\
\hline & $\mathrm{AS}$ & $3(43)$ & $2(29)$ & $2(29)$ & & & 7 \\
\hline
\end{tabular}

Good: ADL 1, 2 Fair: ADL 3 Poor: ADL 4, 5 NG: neurological grade MT: medical treatment VD: ventricular drainage SC: suboccipital craniectomy AS: aspiration surgery $\quad(\quad): \% \quad * p<0.01$

れ，血腫量が 31〜 $100 \mathrm{~m} l$ の症例に血腫吸引術の適応が 西り, $101 \mathrm{~m} l$ 以上の症例では開頭術が望ましいと思わ れた。

\section{2 小脑出血}

小脳出血に対する外科療法の優位性は一般沉認められ ているところである，手術適応を決定する場合，考慮す ベき因子として術前の意識レベルとその推移，脳幹幑 候, CT 所見(血腫径，血腫量，脳室穿破，水頭症な ぞ)，年齢，合併症などがあり，これらに基づいた重症 度分類と手術適応が報告されている。われわれは小脳出 血の重症度を軽症型, 中等症型, 重症型, 激症型の 4 型 に分類している17). 自験 246 例（内科療法 112 例，脳 室ドレナージ 37 例, 後頭下開頭術 59 例, 血腫吸引術 38 例）について，それぞれの治療法の転帰を比較検討 した（Table 1)，意識レベルが清明〜傾眠で，血腫径が $3 \mathrm{~cm}$ 末満（血腫量で $15 \mathrm{~m} l$ 未満）の軽症例は内科療法 で対処でき，外科療法の対象になるのは，血腫量が 15 $\mathrm{m} l$ 以上の重症型（意識レベルが昏迷～半昏睡）と激症 型（意識レベルが昏睡）である．激症型でも呼吸停止や 両側瞳孔散大や聴性脳幹反応のみられない症例は適応と ならない．外科療法のうち，特に激症型では吸引術の成 績が後頭下開頭術よりも優れていた6).

\section{3 視床出血}

視床出血は脳深部にあるため，開頭血腫除去術の適応 はない. 自験 359 例（内科療法 224 例，血腫吸引術 135
例）について，両治療群の成績を比較検討した（Table 2 ). 血腫量が $5 \mathrm{~m} l$ 未満の群と $5 \sim 9 \mathrm{~m} l$ の群では内科療 法と血腫吸引術の成績に差がなく，10～19 $\mathrm{m} l$ の群では 血腫吸引術の機能予後が内科療法より優れており，20 $\mathrm{m} l$ 以上の群では血腫吸引術の死亡率が内科療法より低 かった。したがって，意識レベルが傾眠〜半昏睡で血腫 量が $10 \mathrm{~m} l$ 以上の症例で血腫吸引術の適応があると思わ れた。

\section{4 橋出血}

橋出血に対しては開頭血腫除去術の適応はない22). 自験 6 例の血腫吸引術の成績は, ADL 3 が 1 例, $\mathrm{ADL} 4$ が 3 例，ADL 5 が 1 例，死亡が 1 例であり，救 命率は上がるが必ずしも機能予後はよくなかった。橋出 血に対する定位的血腫吸引術の適応については, 症例数 も少なく確定したものはないが，駒井ら ${ }^{15)}$ は中等度出 血症例(CT上 unilateral type や血腫横径が 22 30 mm）で，機能予後の改善がみられ，重症例で救命率が 優れていると報告している。また，高浜ら ${ }^{299}$ は意識レ ベルが 10〜100，CT 分類では unilateral basis tegmentum type, 最大血腫横径 $22 \sim 28 \mathrm{~mm}$ 程度の症例で は, 座位, 車椅子以上の機能的に良好な手術効果が期待 できるとしている.

\section{5 皮質下出血}

皮質下出血は脳表近くにあり，血腫除去が容易なので よい手術適応となる症例が多い. 自験例は 57 例（内科 
Table 2 Three-month outcome of thalamic hemorrhage

\begin{tabular}{|c|c|c|c|c|c|c|}
\hline \multirow{2}{*}{$\begin{array}{c}\text { Hematoma } \\
\text { volume }\end{array}$} & \multirow{2}{*}{ Treatment } & \multicolumn{4}{|c|}{3 -month outcome } & \multirow{2}{*}{ Total } \\
\hline & & Good & Fair & Poor & Dead & \\
\hline \multirow{2}{*}{$-5 \mathrm{~m} l$} & MT & $61(56)$ & $28(26)$ & $15(14)$ & $4(4)$ & 108 \\
\hline & AS & $4(57)$ & $3(43)$ & $0(0)$ & $0(0)$ & 7 \\
\hline \multirow{2}{*}{$5-9 \mathrm{~m} l$} & $\mathrm{MT}$ & $26(32)$ & $35(43)$ & $15(18)$ & $6(7)$ & 82 \\
\hline & AS & $8(27)$ & $13(43)$ & $5(17)$ & $4(13)$ & 30 \\
\hline \multirow{2}{*}{$10-19 \mathrm{ml}$} & $\mathrm{MT}$ & $3(11)-$ & $15(54)$ & $5(18)$ & $5(18)$ & 28 \\
\hline & AS & $12(25)-$ & $20(42)$ & $11(23)$ & $5(10)$ & 48 \\
\hline \multirow{2}{*}{$20 \mathrm{~m} l-$} & $\mathrm{MT}$ & $0(0)$ & $0(0)$ & $2(33)$ & $4(67)$ & 6 \\
\hline & AS & $1(2)$ & $17(34)$ & $13(26)$ & $19(38)]^{f^{x}}$ & 50 \\
\hline
\end{tabular}

Abbreviations are the same as Table $1 . \quad \mathrm{b}:(\quad): \% \quad *: \mathrm{p}<0.05$

療法 24 例，開頭血腫除去術 17 例，血腫吸引術 16 例） と少なく，現段階では確実な手術適応をいえないが，年 齢が 70 歳未満で意識レベルが傾眠〜半昏睡で，血腫量 が $40 \mathrm{~m} l$ 以上の症例は開頭術が勧められる。年齢が 80 歳末満で，意識レベルが傾眠〜昏迷で血腫量 $20 ５ 9 \mathrm{ml}$ の症例では血腫吸引術の適応になると思われた ${ }^{27)}$ 。東 北地方皮質下出血調查報告によれば，開頭血腫除去術が 内科療法より優れていたのは意識が半昏睡以下のIII群 （3-3-9 度方式）と，上下肢の高度の運動障害がある群 (DeJong の分類の 0,1，2)，血腫量 $40 \mathrm{ml}$ 以上の大血 腫群である．意識がI，II群では死亡率が低い傾向にあ るが，統計学的に有意の差がなかったとしている26). しかし，皮質下出血は血管性あるいは腫瘍性病変が出血 の原因となることがあるので，原因検索のため出血が小 さくても開頭術の適応となる場合がある31).

\section{結 論}

高血圧性脳出血に対する手術法として，開頭血腫除去 術と CT 定位血腫吸引術があるが，それぞれの特徴をよ く理解し，両方の手術法に習熟しておくのが望ましい. 発作から 6 時間以内の早期で，出血が持続しているよう な症例や皮質下出血で出血の原因となる病巣が疑われる 症例は開頭術の適応となる。一方，定位的血腫吸引術も さまざまな方法があるため，自分の施設で利用できる機 器の特徴と限界を十分把握して手術を行う必要がある。 定位的血腫吸引術は開頭術と比べると手術侵襲が少ない ため，より小さな血腫も手術適応となり得るが，その成 績が内科療法の成績を凌ぐ必要がある。

CT 定位血腫吸引術の手術適応については，術前の意 識レベル，血腫量，年齢，合併症などを考慮するが，手 術適応となる血腫量の目安は，被殼出血で $31 \mathrm{~m} l$ 以上， 小脳出血では $15 \mathrm{~m} l$ 以上，視床出血では $10 \mathrm{~m} l$ 以上，皮 質下出血では $20 \mathrm{~m} l$ 以上である．橋出血についてはもう
少し症例を重ねて検討する必要がある。

本論文の内容の一部は，第 18 回日本脳神経外科コングレス (1998 年3月 13 日, 名古屋) において発表した. 論文中の 3DCTAのフィルムを提供していただきました麻植協同病院脳神経 外科の村山佳久先生と, アミロイドアンギオパシーの症例を提供 していただきました高松市民病院脳神経外科の神山悠男先生に感 謝いたします。

\section{文 献}

1) Auer LM: Endoscopic evacuation of intracranial hematomas. Neurosurgeons 6:381-388, 1987.

2) Backlund $\mathrm{E}-\mathrm{O}$, von Holst $\mathrm{H}$ : Controlled subtotal evacuation of intracerebral haematomas by stereotactic technique. Surg Neurol 9: 99-101, 1978.

3）土井英史, 森脇 宏, 駒井則彦, 岩本宗久: 高血圧性脳 出血に対する定位的血腫溶解排除法. Neurol Med Chir (Tokyo) 22: 461-467, 1982.

4）遠藤英雄, 金谷春之, 斉木 巌, 村上寿治, 古川公一郎 : 高血圧性脳出血に対する echo-guided hematoma aspiration の有用性について. 高血圧性脳出血の治療 1，東京，ニューロン社，1986，pp. 94-102。

5) Heilbrun MP, Roberts TS, Apuzzo MLJ, Wells TH Jr, Sabshin JK: Preliminary experience with BrownRoberts-Wells (BRW) computerized tomography stereotaxic guidance system. J Neurosurg 59:217222, 1983.

6) Hondo $\mathrm{H}$, Nishitani K, Izumidani T, Uno M, Shichijo $\mathrm{F}$, Matsumoto $\mathrm{K}$ : Surgical indications for acute hypertensive intracerebral hematomas from viewpoint of our CT-controlled stereotactic operation using ultrasonic hematoma aspiration system. in Kanno T(ed): Brain Hemorrhage '95. Tokyo,Neuron Publ. Co., 1995, pp. 107-115.

7）本藤秀樹：脳血管障害と高血圧管理一脳出血急性期（外 科の立場から)。脳卒中 19：432-436，1997。

8) Iseki $H$, Amano $K$, Kawamura $H$, Tanikawa $T$, Kawabatake H, Notani M, Shiwaku T, Iwata Y, Taira T, Nagao H, Umezawa Y, Shimizu T, Kitamura $\mathrm{K}$ : A mew apparatus for CT-guided stereotactic surgery. Appl Neurophysiol 48:50-60, 1985.

9）伊関 洋，天野恵市：CT 誘導定位脳手術と MRI 誘導 定位脳手術一画像診断装置と定位脳手術の組み合わせに よる種々の治療法について。高倉公朋監：機能神経外 
科，東京，現代医療社，1989，pp. 1-44.

10) Ito $\mathrm{H}$, Mukai $\mathrm{H}$, Kitamura A, Yamashita J: Stereotactic aqua stream and aspirator for hypertensive intracerebral hematoma. Stereotact Funct Neurosurg 53: 77-84, 1989

11）金谷春之：高血圧性脳出血の治療の現況一全国調查の成 績より。脳卒中 12:509-524，1990.

12) Kandel EI, Peresedov VV: Stereotaxic evacuation of spontaneous intracerebral hematomas. $J$ Neurosurg 62: 206-213, 1985.

13) Kato A, Yoshimine $T$, Hayakawa $T$, Tomita $Y$, Ikeda T, Mitomo M, Harada K, Mogami H: A frameless, armless navigational system for computer-assisted neurosurgery: Technical note. $J$ Neurosurg 74:845849, 1991.

14）駒井則彦：CT を利用した定位脳手術。脳外 14：123$133,1986$.

15）駒井則彦，中井易二：定位脳手術による脳幹部出血の治 療。脳卒中 $10: 539-543,1988$.

16）黑田清司，小川 彰：脳内血腫除去術。佐藤 修監，大 井静雄編：Neuroendoscopic Surgery一神経内視鏡の基 礎知識と手術手技. 東京, 三輪書店, 1996, pp. 193198.

17）松本圭蔵，七條文雄：高血圧性小脳出血の重症度分類の 試み。脳神経 34:55-62，1982。

18) Matsumoto $\mathrm{K}$, Hondo $\mathrm{H}: \mathrm{CT}$-guided stereotaxic evacuation of hypertensive intracerebral hematomas. $J$ Neurosurg 61: 440-448, 1984.

19) Matsumoto K, Shichijo F, Masuda $T$, Miyake H: Computer tomography-controlled stereotactic surgery. Appl Neurophysiol 48:39-44, 1985.

20) Matsumoto $K$, Hondo $H$, Tomida $K$ : Aspiration surgery for hypertensive brain hemorrhage in the acute stage. in Suzuki J(ed): Advances in Surgery for Cerebral Stroke. Springer-Verlag, Tokyo, 1988, pp. 433441.

21) Nonomura $K$, Kanno $T$, Katada $K$ : Clinical application of CT-fluoroscopy to the treatment of hypertensive intracerebral hemorrhage. in Kanno $\mathrm{T}$ (ed): Brain Hemorrhage '95. Tokyo, Neuron Publ. Co., 1995, pp. 155-167.

22）落合慈之，佐野圭司，小林 秀，佐々木富男，真柳佳昭 ：橋出血の臨床的検討一とくに CT 所見による分類と手
術適応について。脳神経 31：803-811，1979。

23) Ojemann RG, Heros RC: Spontaneous brain hemorrhage. Stroke 14: 468-475, 1983.

24）乙供共通則，馬杉則彦，大野恒男，渡辺 攻，西川方 夫，佐藤政教，江塚 勇，植村五朗，木戸拓平，吉田顯 正，島 健，木谷隆一，藤本俊一郎，中川 翼，井上信 一, 杉浦和朗, 近藤駿四郎, 狩野光将, 小山照夫，奥 謙, 難波真平, 横山元晴, 伊藤文生, 香川泰生, 横山博 明, 正村和彦, 伊原勝雄, 半田 肇：高血圧性脳内血腫 のてんかん発生に関する調査一被殼部出血における直達 除去例と非手術例の比較。金谷春之編：高血圧性脳出血 の治療 2. 東京，にゅーろん社，1987，pp. 73-88.

25) Patil AA: Computer tomography (CT) orientated rotary stereotactic system: A technical note. Acta Neurochir (Wien) 68:19-26, 1983.

26）桜井芳明：東北地方皮質下出血（特発性）調査報告．脳 卒中 9:579-583，1987.

27）白川典仁，本藤秀樹，松本圭蔵：皮質下出血の外科的治 療の適応と術式の選択。上銘外喜夫編：日本臨牀 1993 年増刊号下巻一CT, MRI 時代の脳卒中学一新しい診 断・治療体系. 大阪, 日本臨牀社, 1993, pp. 192-198.

28）鈴木二郎：脳卒中の外科. 東京, 医学書院，1974.

29）高浜秀俊, 森井 研, 佐藤光弥, 関口賢太郎, 佐藤 進：高血圧性橋出血に対する CT 定位血腫除去術一保存 的治療との比較検討. 脳外 17：733-739，1989.

30）滝沢貴昭, 中村勝重, 小林栄喜：NEURO-SAT：Target centered stereotaxy and image-guided neurosurgery with CT/MRI. 機能的脳神経外科 29:109-116，1990.

31) Wakai S, Kumakura N, Nagai M: Lobar intracerebral hemorrhage: A clinical, radiographic, and pathological study of 29 consecutive operated cases with negative angiography. $J$ Neurosurg 76:231-238, 1992.

32) Watanabe E, Watanabe T, Manaka S, Mayanagi Y, Takakura K: Three dimensional digitizer (neuronavigator): New equipment for computed tomography-guidedstereotaxicsurgery. Surg Neurol 27:543547, 1987.

33）安井信之：高血圧性脳出血の開頭手術. 阿部 弘, 菊池 晴彦, 田中隆一, 坪川孝志, 平川公義, 松本 悟編: 脳 神経外科疾患の手術と適応 II. 東京, 朝倉書店, 1990, pp. 202-236.

高血圧性脳出血の鑑別診断と手術法のポイント，および手術適応について述べた．鑑別診断は血管 撮影 (3D-CTA, MRA を含む), あるいは造影 CTで, 血管性病变や腫瘍性病变を否定しておく 必要がある. 手術法としては, 開頭血腫除去術（経側頭葉法と経シルビウス法）と定位的血腫吸引術 があるが, 両方の手術法に習熟しているのが望ましい. 発作から 6 時間以内で, 出血が持続している 症例は開頭して, 直視下に止血する必要がある. 定位的血腫吸引術の適応になるのは, 被殼出血で 31 $100 \mathrm{~m} /$, 小脳出血で $15 \mathrm{~m} /$ 以上, 視床出血で $10 \mathrm{~m} /$ 以上, 皮質下出血で $20 \mathrm{~m} /$ 以上の血腫であ る. 橋出血の吸引術の適応については, 今後の検討が必要である. 